\title{
Circulating anti-SARS-CoV-2 nucleocapsid (N)-protein antibodies and anti-SARS-CoV-2 spike (S)-protein antibodies in an African setting: herd immunity, not there yet!
}

\author{
Amandine Mveang Nzoghe ${ }^{1 \dagger}$, Marielle Leboueny ${ }^{1 \dagger}$, Eliane Kuissi Kamgaing ${ }^{2,5 \dagger}$, \\ Anicet Christel Maloupazoa Siawaya ${ }^{1 \dagger}$, Eliode Cyrien Bongho ${ }^{1 \dagger}$, Ofilia Mvoundza Ndjindji ${ }^{1}$, \\ Guy-Stephan Padzys ${ }^{4}$, Bénédicte Ndeboko ${ }^{1,5}$, Simon Ategbo ${ }^{3,5}$ and Joel Fleury Djoba Siawaya ${ }^{1^{*}+}$ (i)
}

\begin{abstract}
Objective: Herd immunity is achieved when in a population, immune individuals are in a sufficiently large proportion. Neutralizing antibodies specific to SARS-CoV-2 that are produced following infection or vaccination are critical for controlling the spread of COVID-19. The objective of the present work was to investigate the rate of SARS-CoV-2 natural immunization in Gabonese.

Results: One thousand, four hundred and ninety two people were enrolled. The overall prevalence of anti-SARSCoV-2 antibodies was $36.2 \%$. Moreover, $76.4 \%$ of people who developed a humoral response to SARS-CoV-2 produced both anti-SARS-CoV-2 N-protein antibodies and anti-SARS-CoV-2 S-protein antibodies, which correspond to $27.7 \%$ of the total population. In infants (0-9 month), children (1-17 years) and adults, the prevalence of anti-SARS-CoV-2 antibodies was relatively the same, between 33 and 37\% (any antibody types) and between 25 and 28.6\% (neutralizing antibodies). In this African context, one-third (1/3) of the screened population was exposed to SARS-CoV-2 and threequarter (3/4) of those exposed individuals developed neutralizing antibodies against SARS-CoV-2. This data suggest that herd immunity is not yet to be achieved in Gabon.
\end{abstract}

Keywords: SARS-CoV-2, Antibodies, Infants, Children, Adults

\section{Introduction}

The severe acute respiratory syndrome coronavirus 2 (SARS-CoV-2), the causative agent of COVID-19 is spreading around the globe. Many countries, if not all, are now facing this pandemic. Data shows that all continents

\footnotetext{
*Correspondence: joel.djoba@gmail.com

†Marielle Leboueny, Eliane Kuissi Kamgaing, AnicetChristel Maloupazoa Siawaya, EliodeCyrien Bongho has equal contributions

${ }^{\dagger}$ Amandine Mveang Nzoghe is first author

${ }^{\dagger}$ JoelFleury Djoba Siawaya is last author

1 Service Laboratoire, Centre Hospitalier Universitaire (CHU) - Mère-

Enfant), Fondation Jeanne EBORI, Libreville, Gabon

Full list of author information is available at the end of the article
}

and countries are not equal, and have in some aspects, their COVID-19 epidemic profiles [1-3]. The main argument for Africa's resilience has been the younger age of its population. We need to understand why the virus spreads at different speeds and affects populations differently. To understand why the virus affects populations differently, and assess if SARS-CoV-2 herd immunity should be contemplated naturally or as a result of widescale vaccination programs [4], there is a need to conduct sero-epidemiological investigations.

In Gabon, more than 200000 subjects were screened for SARS-CoV-2 infection (by PCR) from the 13th of

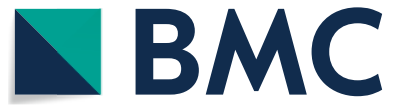

(c) The Author(s) 2021. This article is licensed under a Creative Commons Attribution 4.0 International License, which permits use, sharing, adaptation, distribution and reproduction in any medium or format, as long as you give appropriate credit to the original author(s) and the source, provide a link to the Creative Commons licence, and indicate if changes were made. The images or other third party material in this article are included in the article's Creative Commons licence, unless indicated otherwise in a credit line to the material. If material is not included in the article's Creative Commons licence and your intended use is not permitted by statutory regulation or exceeds the permitted use, you will need to obtain permission directly from the copyright holder. To view a copy of this licence, visit http://creativeco mmons.org/licenses/by/4.0/. The Creative Commons Public Domain Dedication waiver (http://creativecommons.org/publicdomain/ zero/1.0/) applies to the data made available in this article, unless otherwise stated in a credit line to the data. 
March- when the first COVID-19 case was reported- to October 2020. The PCR based prevalence of SARS-Cov-2 was $4.4 \%$ with a death rate among detected cases of $0.6 \%$ (country data). The median age in Gabon is around 20 years old, with more than $60 \%$ of the population under 25 years old. It is in that context that an age-stratified sero-epidemiological study was conducted to determine the extent of SARS-CoV-2 exposure in parts of the population. More precisely we determined the prevalence of anti-SARS-CoV-2 nucleocapsid (N)-protein antibodies and anti-SARS-CoV-2 spike (S)-protein antibodies in Gabonese infants, children and adults.

\section{Main text \\ Methods}

A prospective study was conducted from July to October 2020 in the setting of the Mother and Child University Hospital (CHUMEJE) in Libreville to establish the prevalence of anti-SARS-CoV-2 antibodies by demographic strata. The approach consisted of testing serum from routine activities.

The detection of anti-SARS-CoV-2 antibodies were done using two tests. The first test was the Elecsys ${ }^{\circledR}$ AntiSARS-CoV-2 immunoassay (Roche Diagnostics, France). The Roche test detects pre-dominantly IgG, but also IgA and IgM to SARS-CoV-2 N-protein with a sensitivity of $99.5 \%$ and a specificity of $99.8 \%)$ ). The second test was the VIDAS ${ }^{\circledR}$ SARS-COV-2 IgM/IgG test targeting the Spike protein subdomain (S1/RBD) with a manufacturer declared sensitivity of $96.4-100 \%$ and a specificity of $100 \%$ (Biomerieux, France). Both tests' cutoff index (COI) was one. Assays were conducted following the manufacturers' strict instructions.

The hospital board approved the study, and samples from consenting participants were selected for analysis. Consent was informed and obtained in a written or verbal format (both formats are allowed) based on participant preferences.

\section{Results}

One thousand, four hundred and ninety five people were included in the study: 110 infants aged 9 months and below (7.4\%), 141 children between the age of 1 and 5 years old (9.4\%), 143 children aged between 6 and 17 years old (9.6\%), 993 women aged between 18 and 85 years old (66.5\%) and 108 men aged between 18 and 78 years old $(7.2 \%)$.

The overall prevalence of anti-SARS-CoV-2 antibodies was $36.2 \% .27 .7 \%$ of people developed both anti-SARS-CoV-2 nucleocapsid (N)-protein antibodies and anti-SARS-CoV-2 spike (S)-protein antibodies. Anti-SARS-CoV-2 antibodies prevalence in infants (0-9 months), children (1-17 years), and adults (men and women) were relatively the same, ranging between 33 and 37\% (all antibody types) and between 25 and 28.6\% (both anti-N-protein and anti-S-protein antibodies). Our analysis also showed that $76.4 \%$ of anti-SARS-CoV-2 antibodypositive subjects had both anti-SARS-CoV-2 N-protein antibodies and anti-SARS-CoV-2 S-protein antibodies. $22.4 \%$ of subjects positive for anti-SARS-CoV-2 antibody-positive had only anti-SARS-CoV-2 N-protein antibodies and $1.2 \%$ of subjects positive for anti-SARS-CoV-2 antibody-positive had only anti-SARS-CoV-2 S-protein antibodies.

The Chi-square test of significance showed no differences in immunization status by gender or by age groups. Table 1 shows the prevalence of anti-SARS-CoV-2 antibodies in the studied populations.

\section{Discussion}

Similar to the study by Anand et al., our study used blood collected as part of routine medical care, limiting selection bias [5]. Libreville is the epi-centre of SARS-CoV-2

Table 1 Age and gender stratified prevalence of anti-SARS-CoV-2 antibodies

\begin{tabular}{|c|c|c|c|c|c|c|}
\hline & Age & $\mathrm{N}$ & $\begin{array}{l}\text { Positive for SARS-CoV-2 } \\
\text { antibodies - any test } \\
\mathrm{N}(\%)\end{array}$ & $\begin{array}{l}\text { Positive for both anti-N- } \\
\text { protein and anti-S-protein } \\
\text { antibodies } N(\%)\end{array}$ & $\begin{array}{l}\text { Crude prevalence } \\
\text { (Any type of antibody) } \\
\text { (\%) }\end{array}$ & $\begin{array}{l}\text { Prevalence of both anti-N- } \\
\text { protein and anti-S-protein } \\
\text { antibodies (\%) }\end{array}$ \\
\hline \multirow[t]{2}{*}{ Infants $(N=110)$} & $0-3$ months & 68 & $25(37)$ & $19(28)$ & \multirow[t]{2}{*}{36} & \multirow[t]{2}{*}{27.2} \\
\hline & 4-9 months & 42 & $15(36)$ & $11(26.2)$ & & \\
\hline \multirow[t]{2}{*}{ Children $(N=284)$} & $1-5$ years old & 141 & $44(31)$ & $34(24.1)$ & \multirow[t]{2}{*}{33} & \multirow[t]{2}{*}{25} \\
\hline & $6-17$ years old & 143 & $49(34)$ & $37(26)$ & & \\
\hline \multirow[t]{2}{*}{ Women $(\mathrm{N}=993)$} & $18-44$ years old & 845 & $324(38.3)$ & $247(29.2)$ & \multirow[t]{2}{*}{37} & \multirow[t]{2}{*}{28.5} \\
\hline & 45-85 years old & 148 & $47(32)$ & $36(24.3)$ & & \\
\hline \multirow[t]{2}{*}{ Men $(N=105)$} & 18-44 years old & 63 & $21(33)$ & $16(25.4)$ & \multirow[t]{2}{*}{37} & \multirow[t]{2}{*}{28.6} \\
\hline & 45-78 years old & 42 & $18(43)$ & $14(33.3)$ & & \\
\hline
\end{tabular}

$\mathrm{N}=$ number of participants; \% percentage of participants (prevalence) 
infection in Gabon, concentrating $72 \%$ of cases (country data). In our analysis of the prevalence of SARS-CoV-2 antibodies from patients attending the Libreville mother and child university hospital laboratory services showed that evidence of SARS-CoV-2 exposure in $36.2 \%$ of tested people. The prevalence of SARS-CoV-2 antibodies was comparable in all groups (children and adults). $27.7 \%$ of the population developed both anti-SARS-CoV-2 N-protein antibodies and anti-SARS-CoV-2 S-protein antibodies. Data revealed that $76.4 \%$ of people who developed a humoral response to SARS-CoV-2 produced both antiSARS-CoV-2 N-protein antibodies and anti-SARS-CoV-2 $\mathrm{S}$-protein antibodies. This finding is interesting as it suggests that at least $76.4 \%$ of people naturally exposed to SARS-CoV-2 antigens most probably develop protective immunity.

Currently, there is limited data on mother-to-child passive transfer of anti-SARS-CoV-2 antibodies. With $28 \%$ of newborn infants (aged 0 to 3 months) showing evidence of antibodies against both SARS-CoV-2 N- and $\mathrm{S}$-protein, our study brings further evidence of motherto-child transfer of protective immunity.

Overall, with only $36.2 \%$ of people presenting evidence of circulating anti-SARS-CoV-2 antibodies and 27.7\% had developed a neutralizing immunity, it is safe to presume that Gabon is not near reaching herd immunity. Although there is a very limited number of reports on anti-SARS-CoV-2 antibodies seroprevalence in Africa, we believe that like Gabon, a great number of African countries are far from naturally acquired herd immunity $[6,7]$. In Kenya, the crude seroprevalence of anti-SARSCoV-2 antibody was 4.3\% [7]. The prevalence of antiSARS-CoV-2 antibody observed in South-African ranged from 32 to $63 \%$ [6]. Worldwide the pooled seroprevalence of anti-SARS-CoV-2 antibodies was estimated at 3.6\% (with a maximum of 22\%) [8]. These indicators show a very disparate SARS-CoV-2 exposure across communities and suggest that naturally acquired herd immunity is yet to be achieved worldwide. African immunization through vaccine remains therefore relevant.

The initiative COVAX works to guaranty access to COVID-19 vaccines in all parts of the world, the provision of vaccines for Africa is very limited [9]. We would argue that a great number of African countries will be forced to implement a kind of infection-based herd immunity policy (i.e., letting the low-risk people be naturally exposed to the virus while vaccinating people at higher risk) [10].

\section{Conclusion}

The study showed that one-third (1/3) of the screened population was exposed to SARS-CoV-2 and three-quarter $(3 / 4)$ of those exposed individuals developed neutralizing antibodies against SARS-CoV-2. The relatively low rate of immunization in this study suggests that we are yet to reach herd immunity in this population.

\section{Limitation}

The principal limitation of the study is the small number of subjects in the age-stratified groups of infants and men.

\begin{abstract}
Abbreviations
CHU: Centre Hospitalier Universitaire; COVID-19: Coronavirus disease 2019; COVAX: COVID-19 vaccine access; IgG: Immunoglobulin; PCR: Polymerase chain reaction; SARS-CoV-2: Severe acute respiratory syndrome coronavirus 2.
\end{abstract}

\section{Acknowledgements}

We thank all the study participants. We also thanks and acknowledge Dr. Sikhulile Moyo (Botswana-Harvard AIDS Institute Partnership (BHP) and Harvard T.H. Chan School of Public Health.), Mr Rufus G. Saye (Clinical Health Services Nimba County Liberia) for proofreading the manuscript and his critical comments and Dr Davie Simwaba M (Zambia National Public Health Institute).

\section{Authors' contributions \\ JFDS conceived the study and drafted the first version of the manuscript. JFDS and AMN did data analyses. AMN, ML, EKK, ACMS, ECB, OMN, and GSP did data, sample collection, and laboratory analyses. MKY did data and sample collection. SA and BN participated in the study All authors contributed to the interpretation of data. All authors read and approved the final manuscript.}

\section{Funding}

We would like to acknowledge and thank the Delegation of the European Union in Gabon, Sao Tome, and Principe and Economic Community of Central African States (ECCAS); CHU-Mère-Enfant; Fondation Jeanne EBORI.

\section{Availability of data and materials}

The dataset on which this paper is based on (documentation, raw data file, and methods) used to support this study is available upon request from Prof Joel Fleury DJOBA SIAWAYA (joel.djoba@gmail.com).

\section{Declarations}

\section{Ethics approval and consent to participate}

CHU- Mère-Enfant Fondation Jeanne EBORI board approved the study. All participants gave their consent after being informed of the study objectives. Consent was informed and obtained in a written or verbal format (both formats are allowed) based on participant preferences.

\section{Consent for publication}

Not Applicable.

\section{Competing interests}

The authors declare no competing financial or non-financial interests concerning the present work.

\footnotetext{
Author details

1 Service Laboratoire, Centre Hospitalier Universitaire (CHU) - Mère-Enfant), Fondation Jeanne EBORI, Libreville, Gabon. ${ }^{2}$ Pôle enfant, Service de Néotatologie, CHU-Mère-Enfant Fondation Jeanne EBORI, Libreville, Gabon. ${ }^{3}$ Pôle Enfant Service de Pédiatrie, CHU- Mère-Enfant Fondation Jeanne EBORI, Libreville, Gabon. ${ }^{4}$ Département de Biologie Cellulaire Et Physiologie, Faculté Des Sciences, Université Des Sciences Et Techniques de Masuku, Franceville, Gabon. ${ }^{5}$ Université Des Sciences de La Santé, Libreville, Gabon.
} 
Received: 2 February 2021 Accepted: 13 April 2021

Published online: 20 April 2021

\section{References}

1. Machhi J, Herskovitz J, Senan AM, Dutta D, Nath B, Oleynikov MD, Blomberg WR, Meigs DD, Hasan M, Patel M, et al. The natural history, pathobiology, and clinical manifestations of SARS-CoV-2 infections. J NeuroimmunePharmacol. 2020;15(3):359-86.

2. World-Health-Organization. WHO Coronavirus Disease (COVID-19) Dashboard-Situation by WHO Region. Geneva, London. 2020.

3. Zhang L-P, Wang M, Wang Y, Zhu J, Zhang N. Focus on the 2019 novel coronavirus (SARS-CoV-2). Future Microbiol. 2020;15:905-18.

4. Randolph HE, Barreiro LB. Herd immunity: understanding COVID-19. Immunity. 2020;52(5):737-41.

5. Anand S, Montez-Rath M, Han J, Bozeman J, Kerschmann R, Beyer P, Parsonnet J, Chertow GM. Prevalence of SARS-CoV-2 antibodies in a large nationwide sample of patients on dialysis in the USA: a cross-sectional study. Lancet. 2020;396(10259):1335-44.

6. Chibwana MG, Jere KC, Kamng'ona R, et al. High SARS-CoV-2 seroprevalence in health care workers but relatively low numbers of deaths in urban Malawi [version 1; peer review: 1 approved, 1 approved with reservations]. Wellcome Open Res. 2020;5:199. https://doi.org/10.12688/ wellcomeopenres.16188.1.

7. Uyoga S, Adetifa IMO, Karanja HK, Nyagwange J, Tuju J, Wanjiku P, Aman R, Mwangangi M, Amoth P, Kasera K, et al. Seroprevalence of anti-SARS-CoV-2 lgG antibodies in Kenyan blood donors. Science. 2021;371(6524):79-82.

8. Rostami A, Sepidarkish M, Leeflang MMG, Riahi SM, NourollahpourShiadeh M, Esfandyari S, Mokdad AH, Hotez PJ, Gasser RB. SARS-CoV-2 seroprevalence worldwide: a systematic review and meta-analysis. ClinMicrobiol Infect. 2021;27(3):331-40.

9. World-Health-Organization. More than 150 countries engaged in COVID19 vaccine global access facility. Geneva, London. 2020.

10. Omer SB, Yildirim I, Forman HP. Herd immunity and implications for SARSCoV-2 control. JAMA. 2020;324(20):2095-6.

\section{Publisher's Note}

Springer Nature remains neutral with regard to jurisdictional claims in published maps and institutional affiliations.
Ready to submit your research? Choose BMC and benefit from:

- fast, convenient online submission

- thorough peer review by experienced researchers in your field

- rapid publication on acceptance

- support for research data, including large and complex data types

- gold Open Access which fosters wider collaboration and increased citations

- maximum visibility for your research: over $100 \mathrm{M}$ website views per year

At BMC, research is always in progress.

Learn more biomedcentral.com/submissions 